\title{
Artificial Insemination of Sheep - Possibilities, Realities and Techniques at the Farm Level
}

\author{
Sándor Kukovics' ${ }^{1}$ Erzsébet Gyökér², \\ Tímea Németh ${ }^{1}$ and Elemér Gergátz ${ }^{2}$ \\ ${ }^{1}$ Research Institute for Animal Breeding and Nutrition \\ ${ }^{2}$ Pharmagene-Farm Ltd, Biotechnical Research Station \\ Hungary
}

\section{Introduction}

\subsection{History of artificial insemination over the last $\mathbf{5 0}$ years}

The state of artificial insemination in the sheep and goat industries has developed differently in Europe over the last couple of decades. The number of artificial inseminations in the sheep industry and the ratio of inseminated ewes increased sharply in East Europe, especially in the eastern part of Mid-Europe, during the 1950s and 1960s. The main reason for this increase could be due to the planned economy and certain central pressure from the state. The presence and the ratio of use of this method were much lower in other parts of Europe, and its development was rather slower.

Because of unfavourable economical circumstances, the profitability of the sheep industry fell in the eastern part of Europe and the number of sheep kept on big state and cooperative farms declined during the 1970s and the second half of the 1980s. With the changing economy in the early 1990s, the decline in sheep number continued. In Hungary, in particular, during the preparation period prior to accession to the EU, there was a sharp increase in sheep number, with the increasing trend lasting until the end of 2005. The trend has reversed since then, with a gradual and intensive reduction.

As the consequences of the use of artificial insemination (AI) with semen from imported breeding rams, wool production traits (fibre diameter, shearing, greasy wool weight and staple length among others) have steadily and gradually increased in Hungarian Merino flock. Artificial insemination centres were founded by the state between early 1950s and the end of the 1970s. Some regional sub-stations belonging to each county AI centres were supplying flocks from state and cooperative farms. Over this period, the state helped improve sheep breeding with the operation of AI centres. The number of inseminated ewes reached its peak in the mid 1960s, when $63 \%$ of ewes in the national flock were artificially inseminated with a relatively wide range, but from the end of this decade, the use of AI started to go back. In the Hajdu-Bihar County (east of the country) for instance, the number of inseminated ewes exceeded 85\%, even in mid 1970s' (Kukovics, 1974; Jávor et al., 2006; Kukovics \& Gergátz, 2009). From the mid 1970s, the state-owned artificial insemination centres started to close down, the number of rams kept for semen collection was reduced and the breeding animals were sold to various farms. 
After this period privately-owned self-owned ram and artificial insemination units were established and took advantage of the sheep breeding state and cooperative farms.

Meanwhile, artificial insemination started to be more intensively used in Western Europe. The number of inseminated ewes and their ratio increased in breeding programmes where rapid genetic development was essential. One of these programmes was the French dairy Lacaune breeding system, where more than $82 \%$ of the nucleus part of the population (about 160000 out of the 750000 heads) were artificially inseminated by 1993 with semen mainly transported from several AI centres. During the previous thirty years, average milk production increased from 50 to 70 litres to 300 litres per ewe annually (Barillet et al., 1993). This trend did not change and the system expanded to other breeds in France, Spain and Italy (Jávor et al., 2006).

Since the beginning of the 1980s, the number of inseminated ewes has decreased noticeably in Hungary. As the whole economy of the country was reorganised and privatised from the early 1990s, the number of farms utilising AI as the breeding method has almost disappeared. Nowadays, less than $2 \%$ of breeding ewes are inseminated artificially on about 15 to 20 farms out of the registered 6,900 sheep farms. Indeed, the relatively small size of flocks (about 150 heads of adult females) has an important role in the development of this situation. Almost twenty breeds are bred in the country, but AI is only used in limited numbers. The Merinos are the dominant breed in the country; however, very few farmers breeding Merino sheep use AI.

It was quite well known many years ago and even today that AI can not be carried out without special skills. Several hundred people were educated on artificial insemination (in the 1950s and 1960s up to the mid 1970s) in order to use this modern breeding method in the country.

The education of shepherds practically decreased in Hungary, and no one received even minimal skills in the AI of sheep and goats between 1986 and 1999. On behalf of the Hungarian Goat Breeders Association and the Hungarian Sheep Dairying Association, a series of indoor courses were organised for sheep and goat breeders in 1999 and 2000. The courses were carried out in the Biotechnical Research Station University of Western Hungary, in Mosonmagyaróvár. More than 60 people (shepherds and goat breeders) finished the three courses and took successful theoretical and practical examinations, receiving a certificate for their knowledge. Unfortunately, the organisation of further courses had to be stopped because of a shortage of funds needed to cover the costs of the courses. However, a couple of years later, special official courses were announced by the state in sheep and goat AI, but there was no interest until now.

At present, only a limited number of breeders are convinced about the importance and the value of AI. Most of the sheep and goat keepers have several numbers of breeding males for mating.

Until 2008, two officially certificated artificial insemination stations (Pharmagene-Farm Ltd, Mosonmagyaróvár, and Bakonszegi Awassi Corporation, Bakonszeg) were operating in the country; however, some research centres (universities and research institutes) had complete laboratories ready to offer services to various farms. In 2011, only one AI station remained active in Mosonmagyaróvár, and there was a new embryo transfer station officially certified in Budapest.

Unfortunately, not only is there a shortage of state-organised shepherds as well as a lack of educating inseminators (cattle and pig excluded), but there is also an absence of interest of the breeders association in forcing farmers to get knowledge and use artificial insemination. 
The lack of interest, insufficient knowledge and education, absence of organisation, laziness, shortage of labour and low profitability can be found behind this symptom.

The director of Hőgyész State Farm, Béla Szülló (Hungary), who supervised the breeding and production of more than 4,000 sheep stated in 1972, believed that the profitability of meat sheep farming could be achieved when 1.5 lambs could be utilised after one ewe annually (Kukovics, 1974). This level could be attained with the use of frequent lambing, utilisation of artificial insemination, and with the application of breeds with high prolificacy in crossbreeding programmes. That result was later confirmed by Kukovics \& Jávor (2002) in their study.

\subsection{The main factors affecting Al}

There are several factors that could modify the effectiveness of artificial insemination and some of them are mentioned below.

\subsubsection{The breed}

In many publications, the ewe breed has been found to have a large effect on the pregnancy rate after artificial insemination. According to Hill et al. (1998), the wool type (strong wool 67.6\%; fine wool - 71.7\%; fine medium and medium 73\%) of Australian Merino affected the average pregnancy rate. In a Greek study (Karagiannidis et al., 2001), the conception rate rank of ewes was Chios, Vlachiki and (Vlachiki x Chios), with a significant difference between them. The pregnancy rate of Suffolk ewes was much lower $(12 \%)$ than that of Finnish landrace (65\%) in Irish studies (Donovan et al., 2001 and 2004), while the breed of the ram also had a significant effect on prolificacy after AI (Perkins et al., 1996; Donovan et al., 2001 and 2004; Anel et al., 2005).

\subsubsection{Age of the ewe}

The fertility rate in laparoscopic insemination gradually decreases from the age of 1.5 to 2.5 years (Anel et al., 2005), while it increases until 3.5 to 4.5 years of age in vaginal insemination.

\subsubsection{The season of insemination}

The season of insemination could have a strong effect on the results. According to Hill et al. (1998), the month of insemination exerted highly significant differences: it was $71.5 \%$ in March, April, or May and 67.6\% in November, December, January or February. In the study of Anel et al. (2005), the season modified the conception rate after both laparoscopic and vaginal insemination (September-January 46.88 vs. 35.53\%; February-June 43.96 vs. 29.79 \%; July-August 38.95 vs. $22.72 \%$ ), but the data of the first one were always higher.

\subsubsection{The use of fresh, cooled, chilled, frozen semen}

It is generally stated that the fertility of the semen decreases with cooling temperature. The use of freshly diluted semen could give the best result: 70 to $82 \%$ (Donovan et al., 2001 and 2004) and 82.2\% (Hill et al., 1998; Ehling et al., 2003). A similar level could be reached with cooled and stored semen /74-76\% (Gergátz\&Gyökér, 1997) and 56.7\% (Fernandez-Abella et al., 2003) as well as with chilled and stored semen / between 37.5\% (Fernandez-Abella et al., 2003) and 64.2-73.33\% (Stefanov et al., 2006)/. The conception rate frozen-thawed semen was the lowest in all of the publications: 38 to $46 \%$ (Gergátz \& Gyökér, 1997), 69.5 to 71.6\% 
(Hill et al., 1998), 29 to 52\% (Donovan et al., 2001, 2004), and 42.86 to $53.33 \%$ (Stefanov et al., 2006).

\subsubsection{The labour}

In the study of Anel et al. (2005), the results of laparoscopic (from 40.60 to $51.54 \%$ ) and vaginal (from 23.85 to $43.16 \%$ ) insemination highly depended on the technician who carried it out.

\subsubsection{The year}

Anel et al. (2005) reported that the level of pregnancy rate decreased for both techniques (from 62 to $44 \%$ for laparoscopic AI and from 38 to 31\% for vaginal AI) between 1990 and 1997.

\subsubsection{Time of insemination after oestrus synchronisation}

The time of $\mathrm{AI}$ is especially important in the case of oestrus synchronisation. The best time of insemination could be 46 (Fernandez-Abella et al., 2003), 48 to 72 (Karagiannidis et al., 2001), and 58 to 63 (Donovan et al., 2001, 2004) hours after the pessary removal.

\subsubsection{Dose of PMSG used}

Hill et al. (1998) reported that the type and dosage of PMSG (Pregnant Mare Serum Globulin - $200 \mathrm{IU}-62.4 \%$; $250 \mathrm{IU}-72.9 \%$; $300 \mathrm{IU}$ - 79.1\%; $375 \mathrm{IU}$ and above - 69.4\%) had a significant effect on the conception rate in artificial insemination.

\subsubsection{The extender used}

The main aim of diluting is to enlarge the fertility and storing ability of ram semen (Mucsi, 1997; Sarlós, 1999; Gergátz, 2007) with additional energy. There are many kinds of extenders used for this reason (skimmed milk, Ivanov, Salamon, improved versions of them, etc. (Kukovics, 1974; Becze, 1982, Gergátz \& Gyökér, 1997; Sarlós, 1999; Fernandez-Abella et al., 2003; Jávor et al., 2006), and most of the authors suggest materials. The semen used in any kind of artificial insemination is mainly diluted, and dilution is particularly important in the case of cooling, chilling and deep freezing of semen. The most common dilution rate is the 1:1 - 1:2 - 1:3 - 1:4, but in practice, a ratio higher than 1:8 is not really used (FernandezAbella et al., 2003; Gergátz, 2007).

\subsubsection{Dose of inseminated semen}

In general, the suggested dose of semen is 0.1 to $0.2 \mathrm{ml}$ with about 50 to 100 million active spermatozoa. About 50 to 100 million spermatozoa is needed in one dose to vaginal insemination, but 25 to 50 million are suggested for cervical insemination and 15 to 20 million is enough for laparoscopic AI (Kukovics, 1974; Jávor et al., 2006; Gergátz, 2007). However, several scientists have used much higher numbers: 106 (Fernandez-Abella et al., 2003), 50 to 300 (Ehling et al., 2003) and 400 (King et al., 2004) million spermatozoa in one dose of semen.

\subsubsection{The method (vaginal, cervical, cervico-uterinal or laparoscopic) used}

The simplest method is vaginal insemination, which could result in the lowest conception rate. The use of cervical and trans-cervical methods could give much higher pregnancy 
rates, but laparoscopic $\mathrm{AI}$ is the most effective one. However, it is also the most expensive and complicated method. Apart from the general trends, the publications show quite a wide range of rates: 31.25\% (Anel et al., 2005) in vaginal, 18 (Yamaki et al., 2003); 42 (King et al., 2004); and 65-75\% (Salamon \& Maxwell, 1995; Donovan et al., 2001, 2004; Stefanov et al., 2006) in cervical; 69.6 to $76.4 \%$ (Szabados, 2006) in cevico-uterinal; and 44.89 (Anel et al., 2005), 64 (Yamaki et al., 2003), and 69 \% (King et al., 2004) in laparoscopic insemination. It should be noted that these results are affected according to the semen used (fresh, cooled, chilled or frozen (Perkins et al., 1996; Moses et al., 1997).

\subsection{Detection of ewes on heat and the number on inseminations}

One of the key questions of artificial insemination is the detection of ewes on heat, the time of insemination following the selection, and the number of inseminations made. The main detection systems could be summarised as follows (Kukovics, 1974; Jávor et al., 2006):

I. Selection once a day ( 24 hours) in the morning (or in the afternoon)

(A) first insemination made immediately

(a) insemination every 24 hours

1. no further insemination

2. second insemination made without further selection

3. second insemination only in the case of when heat is detected

4. further insemination in the case that the ewe is still on heat

4.1. no more than three inseminations

4.2. further inseminations until the animal is on heat

(b) insemination every 8 to 12 hours

sub-points are the same as in point (a)

(B) the first insemination made 3 to 4 hours after selection or later

sub-points are the same as in point $(\mathrm{A} / \mathrm{a})$

II. Selection every 8 to 12 hours

(A) insemination made right after detection

(a) no further insemination made

(b) further inseminations every 8 to 12 hours

sub-points are the same as in point I. (A/a)

(B) first insemination made 3 to 4 hours after detection or later

sub-points are the same as in point I. (A/a)

Since heat in ewes lasts 24 hours, in general, and is shorter in the case of yearlings, the first (I) method could have several limitations and so, the second (II) method is proposed and could be more effective.

Concerning the daily distribution of real heats, adjusted to the possibilities of practical life, the ewes on heat are detected between 6 and 7 hours in the morning as part of the so called "Mosonmagyaróvár insemination technique" (Gergátz, 2007). The first insemination is carried out between 10 and $11 \mathrm{am}$, and the second one between 3 and $4 \mathrm{pm}$. Because of the once daily detection, about $5 \%$ of the yearlings will be omitted from insemination at first, but $95 \%$ of them will be inseminated in the next heat.

Many opponents of artificial insemination declare that using this method, the level of pregnancy obtained naturally cannot be performed. The results of studies from the last decades have proved that the pregnancy rate of ewes selected and inseminated only once could reach 60 to $65 \%$. The pregnancy rate of the ewes selected and inseminated twice during the same cycle could exceed $75 \%$ and reach 80 to $85 \%$. With the use of three 
inseminations, 90 to 95\% of pregnancy could be performed (Kukovics, 1974; Jávor et al., 2006; Gergátz, 2007).

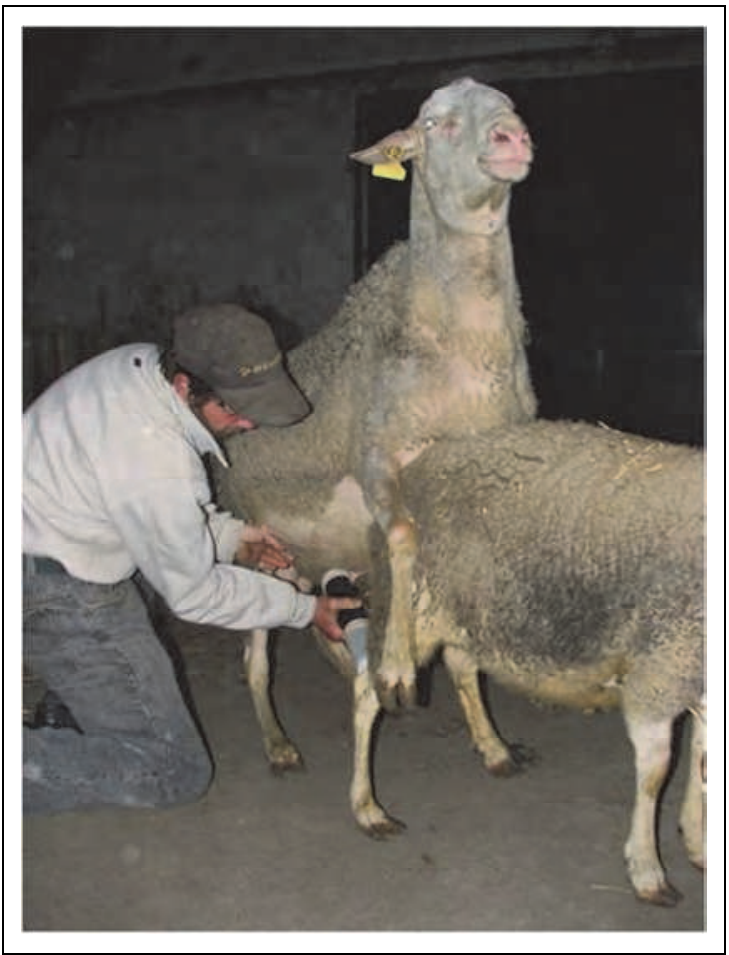

Fig. 1. Collection of semen at a farm (Photo: Németh, A.)

\subsection{The costs of artificial insemination}

It is rather difficult to estimate the costs of artificial insemination per average ewe on a farm. The following jobs and movements are involved: preparation of rams and ewes for AI, preparing equipments and tools for collecting semen and artificial insemination, collecting, qualifying, diluting and dosing semen, detecting and selecting ewes on heat, fixing animals to carry the AI, and finally performing the insemination, and cleaning the tools and equipments. These basically cover the expenditures of buying tools (and feeds) and the costs of labour. The use of oestrus synchronisation is an additional cost, even if it consists of several parts.

The cost of artificial insemination increased from 1.2 to $3.2 \mathrm{HUF} /$ head to 2.5 to 4.5 HUF/head between 1966 and 1971 in the abovementioned Hajdú-Bihar County (Kukovics, 1974). This increase was the consequence of the intensive development of feed prices (especially the crops and concentrates). In order to evaluate current values (2010), these numbers should be multiplied by 100 to 500 (in 20111 Euro $=270$ HUF approx.)

The estimated costs of artificial insemination change according to the method utilised, the places of semen collection, the labour/service company that is performing the job, the presence of oestrus synchronisation, and the handling of rams before the season, among 
others. Laparoscopic AI is the most expensive because it needs veterinary service and help. At the same time, vaginal, cervical or even trans-cervical insemination can be carried out by well-skilled shepherds, at a much lower level of costs, without significant losses in efficiency.

Due to reorganisation of the national economies of Mid-East European countries, stateowned AI centres have disappeared (Jávor et al, 2006) and most of the remaining sheep farms use rams for natural services. Shepherds educated on performing AI have either died or have left the sheep industry and the remaining ones do not want to work with it as it means extra work, attention and accuracy. AI is only used on very few farms nowadays and available data on expenditures of AI are rather limited or not published at all.

In Western Europe and the Western world, artificial insemination became a special service of companies, not really based on the skills of sheep owners and shepherds. At the same time, laparoscopic AI (LAI) has become the most popular, which can be carried out by veterinarians. Cervical and trans-cervical AI can also be provided by different veterinary and genetic companies.

Donovan et al. (2001) stated that cervical insemination was much cheaper than laparoscopic $\mathrm{AI}$, but exact cost values were not given in the study. After out-of-season mating (May) of purebred and crossbred Lacaune ewes with oestrus synchronisation and induction, Gulyás et al. (2007) reported that the extra costs of using biotechnological methods were refunded with the good profits raised by selling lambs during Christmas time. According to an American presentation for sheep farmers, cervical and trans-cervical methods are easy to learn and use. Each sheep takes about two minutes to inseminate at a cost of \$1.29, making it significantly faster and less expensive than laparoscopic surgical insemination

(http://www.farmanddairy.com/news/ultrasound-and-artificial-insemination-techniques). The service charges of these companies are quite different, and most of them concerning only LAI do not cover all the costs. The service cost of LAI could be, for instance, GBP 10 to 15 per ewe (http://www.innovis.org) or GBP 10 to 25 per ewe plus indirect cost, which means the total costs could be around GBP 20 to 35 per ewe (http:/ / www.trialanderroracres.com); or AU\$ 15 to 30 per ewe (Genstock Animal Breeding Services, Australia - http://genstock.com.au) ; or NZ\$ 15 to 30 (Genetic Gains Ltd and Premier Genetics Ltd, New-Zealand - http://genetic-gains.co.nz), or the prepared semen could be ordered at the price of US\$ 15 to 135 per straw (Super Sire Ltd - Pathway to Genetic Improvement - http://www.topRams.com). Apart from these, limited data are available about the real costs of AI. The service reports and offers discuss pregnancy rate levels and the charges.

\section{Materials and methods}

As mentioned above, less than $2 \%$ of the ewes kept in Hungary were artificially inseminated between 2000 and 2010; however, more than $63 \%$ of ewes were artificially inseminated in 1963. Examining the main characteristics of more than 6,900 sheep farms and about 500 goat farms, we observed that AI was utilised only on a limited number of sheep farms, and no goat farm practically used this breeding method.

\subsection{The farms and the breeds kept}

In order to study artificial insemination at the farm level, 11 sheep farms out of the less than 20 farms with available data were selected from 2003 to 2010. Twelve breeds and genotypes 
of sheep were breed on the studied farms. The breeds kept on the various farms and the number of years when artificial insemination was utilised are summarised in Table 1.

On most farms, only one breed was kept, but three different breeds were bred on farm No. 2, 9 and 10, and two breeds on farm No. 11.

In the first farm, which was a corporation, a breeding project has been carried out since 1990 and purebred Awassi and crossbred Awassi $\left(F_{1}, R_{1}, R_{2}, R_{3}, R_{4}\right)$ flocks have been reared. The majority of female sheep was artificially inseminated during 2003 to 2007, but because of low AI efficiency, natural insemination with breeding rams was used to get better pregnancy results. The farm was finally reorganised and sold in 2009 , so the use of AI ended from 2008.

A breeding project was performed on the second farm, which was a state farm aiming to create a new synthetic breed and started operating from early 1970s. The Bábolna Tetra sheep breed was finally developed from the crossings of Hungarian Merino as well as 5 lines of Finnish Landrace and 3 lines of Romanov breeds, and it was officially accepted as a new breed in 1995. In addition to this, Ile the France and American Suffolk nucleus flocks were also developed on the farm, starting in 1988. The reorganisation and final selling of the farm and its sheep happened in 2009 and 2010, and it is currently a much smaller private farm.

\begin{tabular}{|c|l|c|}
\hline $\begin{array}{c}\text { Farm } \\
\text { code }\end{array}$ & No. and name of breeds kept & No. of years \\
\hline 1 & 1: Awassi and Awassi crossbreds & $5(2003-2007)$ \\
\hline 2 & 3. Bábolna Tetra, Ile de France, Suffolk & $8(2003-2010)$ \\
\hline 3 & 1: Hungarian Merino & $4(2003-2006)$ \\
\hline 4 & 1: German Mutton Merino & $6(2003-2008)$ \\
\hline 5 & 1: Hungarian Merino & $6(2003-2008)$ \\
\hline 6 & 1: Lacaune & $2(2009-2010)$ \\
\hline 7 & 1: Lacaune & $7(2003-2010)$ \\
\hline 8 & 1: Lacaune & $2(2003-2004)$ \\
\hline 9 & $\begin{array}{l}\text { 3: Hungarian Merino, German Mutton Merino, } \\
\text { German Blackheaded Mutton Sheep }\end{array}$ & $8(2003-2010)$ \\
\hline 10 & 3: British Milksheep, Charollais, Hungarian Merino & $5(2005-2010)$ \\
\hline 11 & 2: British Milksheep, British Milksheep Crossbreds & $8(2003-2010)$ \\
\hline
\end{tabular}

Table 1. Number of breeds and the studied years on the farms

The other private farms were founded in the 1990s, when most of the cooperative and state farms were demolished, reorganised and the sheep were sold from them. The only exception was farm No. 7, which was a research station belonging to the University of West Hungary founded in 1982, and it is still a research station.

The use of AI stopped on farm No. 3 in 2007, and in 2009 in the case of farms No. 4 and 5 because of labour problems. On farm No. 8, the labour problem together with the low quality of AI made with transported semen led to the replacement of AI with the use of extra breeding rams.

On farm No. 10, only a small population of the sheep (purebred imported breeds) were artificially inseminated, and the AI started to be utilised in the nucleus part of the Merino flock only in 2007. On farm No. 12, the British Milksheep crossbred sheep (Hungarian 
Merino x British Milksheep) were handled separately since 2007. On farm No.6, the use of AI was only started in 2009.

The results of AI were not possible to evaluate for year 2010 in the case of farms No. 6, 7, 10 and partly 11 because the lambing of artificially inseminated ewes started only in 2011 and was not finished before the time of data collection.

\subsection{Data collection}

Two surveys were carried out in late 2007 and at the beginning of 2011 in order to collect data of artificial insemination on the selected farms. Each farm was visited and the data was collected based on a questionnaire covering the following information:

- number of sheep kept,

- number of artificially inseminated ewes per breed and per year,

- number of progeny born and weaned after AI per breed and per year,

- method of selection and time searching ewes on heat,

- time and number of insemination,

- method of collecting and qualifying semen to use,

- level of dilution, kind of extender and the size of inseminating dose,

- method and use of oestrus synchronisation,

- method of insemination,

- fixing method of ewes during insemination,

- control of pregnancy and use of ram service after insemination,

- number of labour used over AI,

- cost of AI.

\subsection{Processing of data}

The methods of AI used on various farms were evaluated in details. The results of AI were studied on farm levels because of the farm difference in the number of breeds kept.

$$
\begin{array}{ll}
\text { Pregnancy rate }(\mathrm{P} \%)= & \frac{\text { lambed ewes }}{\text { inseminated ewes }} \\
\text { Lambing rate }(\mathrm{L} \%)= & \text { born lambs } \\
\text { lambed ewes } \\
\text { Weaning rate }(\mathrm{W} \%)= & \text { weaned lambs } \\
\hline
\end{array}
$$

The pregnancy rate $(\mathrm{P} \%)$, lambing rate $(\mathrm{L} \%)$ and the weaning rate $(W \%)$ were calculated by farms and by breeds in every studied year. In the case of those farms where more than one breed was kept, the effects of breed and year were studied. In the case of farms where only one breed was kept, the effects of year were examined.

Chi-square test of SPSS 10.0 was applied to compare the breeds to each other and to compare the years by breed. Significant differences between breeds and years were determined at $\mathrm{P} \leq 0.05$. 


\section{Results}

The total number of sheep kept on various farms is summarised in Table 2 . The size of flocks belonging to various breeds per farm changed over the studied period, the number of ewes mainly decreasing over the years. The numbers of artificially inseminated ewes per breed and per farm are presented in Table 3.

\subsection{The tools of artificial insemination}

The most important factors in artificial insemination are well-skilled labour (mainly shepherds or inseminators), well-prepared rams of good quality, ewes with good body condition, and the necessary equipments and tools.

Based on our study, at least one person per farm with proper skill in artificial insemination was working, and he was primarily the owner shepherd. There were technicians on farms No. 1 and 7. The animals were prepared (details presented later on) on each farm before the season.

The most important equipments and tools necessary for performing artificial insemination on farms are shown in Figure 2: artificial vagina, semen collecting glass with double wall (and warm water between the walls), warm water bath, thermometer, vaginal speculum (with different size for adult ewes and ewe hoggets), lamp for providing light into the vagina, pipettes, catheter, syringe and vaginal sponges or implants for oestrus synchronization. A microscope with relatively smaller capacity is also needed with a table and sheet object heater.

\begin{tabular}{|c|c|c|c|c|c|c|c|c|}
\hline $\begin{array}{c}\text { Farm } \\
\text { code }\end{array}$ & 2003 & 2004 & 2005 & 2006 & 2007 & 2008 & 2009 & 2010 \\
\hline 1 & 1960 & 2120 & 2140 & 2200 & 2080 & - & - & - \\
\hline 2 & 3138 & 2905 & 2753 & 2103 & 2251 & 2170 & 971 & 588 \\
\hline 3 & 312 & 359 & 411 & 461 & 450 & - & - & - \\
\hline 4 & 700 & 700 & 750 & 700 & 840 & 834 & - & - \\
\hline 5 & 820 & 900 & 950 & 980 & 1050 & 960 & - & - \\
\hline 6 & - & - & - & - & - & - & 1100 & 980 \\
\hline 7 & 239 & 204 & 177 & 206 & 216 & 237 & 295 & 290 \\
\hline 8 & 588 & 456 & - & - & - & - & - & - \\
\hline 9 & 1160 & 1168 & 1183 & 1157 & 988 & 1060 & 968 & 940 \\
\hline 10 & - & - & 430 & 450 & 470 & 460 & 460 & 450 \\
\hline 11 & 420 & 390 & 350 & 380 & 380 & 350 & 345 & 340 \\
\hline
\end{tabular}

Table 2. The total number of ewes kept on the studied farms between 2003 and 2010 


\begin{tabular}{|c|c|c|c|c|c|c|c|c|c|c|}
\hline $\begin{array}{c}\text { Breed, } \\
\text { farm } \\
\text { code, } \\
\text { year }\end{array}$ & \multicolumn{9}{|c|}{ Hungarian Merino } & \multicolumn{2}{|c|}{$\begin{array}{c}\text { German } \\
\text { Mutton } \\
\text { Merino }\end{array}$} & $\begin{array}{c}\text { German } \\
\text { Blackheaded } \\
\text { Mutton Sheep }\end{array}$ & \multicolumn{2}{|c|}{$\begin{array}{c}\text { British } \\
\text { Milksheep }\end{array}$} & $\begin{array}{c}\text { British } \\
\text { Milksheep } \\
\text { Crossbreds }\end{array}$ \\
\hline 2003 & 446 & - & 274 & 160 & 438 & 640 & 174 & - & 420 & - \\
\hline 2004 & 458 & - & 350 & 200 & 461 & 650 & 159 & - & 390 & - \\
\hline 2005 & 477 & - & 385 & 220 & 476 & 690 & 171 & 33 & 350 & - \\
\hline 2006 & 440 & - & 317 & 350 & 462 & 600 & 179 & 41 & 280 & - \\
\hline 2007 & 522 & 118 & - & 165 & 319 & 650 & 147 & 31 & 280 & 70 \\
\hline 2008 & 563 & 150 & - & 130 & 335 & 670 & 162 & 28 & 240 & 60 \\
\hline 2009 & 498 & 150 & - & - & 288 & - & 182 & 41 & 235 & 60 \\
\hline 2010 & 475 & $150^{*}$ & - & - & 310 & - & 155 & $70^{*}$ & $240^{*}$ & $65^{*}$ \\
\hline
\end{tabular}

\begin{tabular}{|c|c|c|c|c|c|c|c|c|}
\hline $\begin{array}{c}\text { Breed, } \\
\text { farm } \\
\text { code, } \\
\text { year }\end{array}$ & Charollais & \multicolumn{3}{|c|}{ Lacaune } & Awassi & $\begin{array}{c}\text { Bábolna } \\
\text { Tetra }\end{array}$ & $\begin{array}{c}\text { Ile de } \\
\text { France }\end{array}$ & Suffolk \\
\hline 2003 & - & 212 & 198 & - & 1960 & 1717 & 937 & 195 \\
\hline 2004 & - & 196 & 127 & - & 2120 & 1379 & 996 & 245 \\
\hline 2005 & - & 165 & - & - & 1760 & 1222 & 863 & 240 \\
\hline 2006 & - & 151 & - & - & 370 & 1147 & 732 & 224 \\
\hline 2007 & 11 & 167 & - & - & 50 & 1014 & 866 & 214 \\
\hline 2008 & 8 & 127 & - & - & - & 1043 & 784 & 304 \\
\hline 2009 & 16 & 245 & - & 297 & - & 311 & 310 & 242 \\
\hline 2010 & $18^{*}$ & $255^{*}$ & - & $369^{*}$ & - & 286 & 186 & 107 \\
\hline
\end{tabular}

* lambing after AI made in 2010 started in 2011

Table 3. Distribution of the number of inseminated ewes by breed and farms 
Based on the results of our survey (visiting the eleven farms), all necessary tools and equipments were available. Moreover, officially-accepted artificial insemination stations were operating on farms No. 1 and 7, from where semen could be bought by other farms.

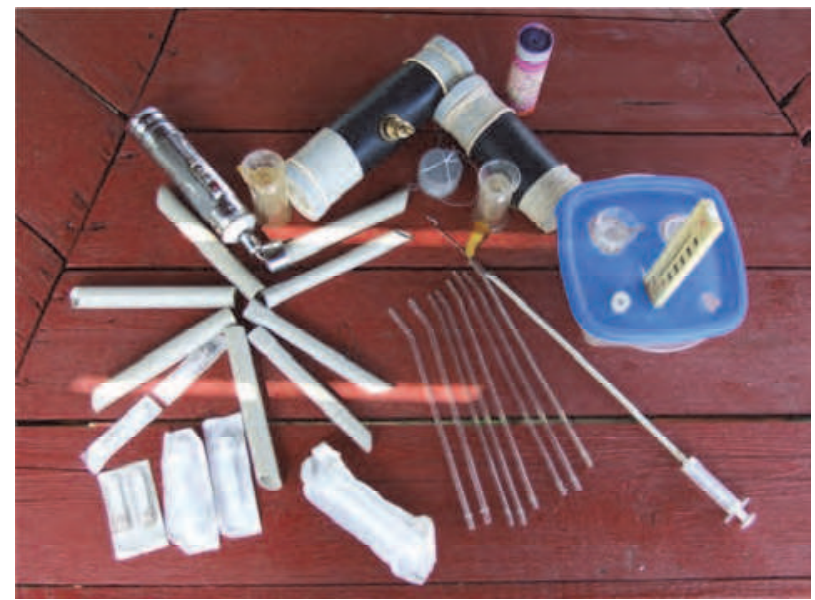

Fig. 2. The equipments and tools for artificial insemination (Photo: Kukovics, S.)

\subsection{Preparing the animal for the mating (inseminating) period}

The preparation of rams and ewes for the mating (inseminating) period was a common practice on all farms. In the case of rams, the level of nutrition started to improve at least four weeks before the planned season. Parallel to this, the training of the rams was also initiated and semen was collected at least two times a week. The quality of the semen was studied.

\subsubsection{Preparing ewes and using oestrus synchronisation}

Oestrus synchronisation and induction are highly recommended in the case of using artificial insemination. Yet these methods were not commonly utilised on the studied farms during the period under study. The nutritional method (flushing started four weeks before $\mathrm{AI}$ ) was used on every farm in order to prepare the ewes for the mating period. The ram effect was not really used. However, on some farms, vasectomised rams were introduced to the flock of ewes, but it was not correctly planned. No other method (like reducing the length of light hours) was used on these farms.

Oestrus synchronisation and induction were used on only five farms (No. 1, 5, 6, 7 and 10). These methods were used during the main season and in spring time on farms No. 1 and 10 (only in the case of Merinos), only in spring on farms No. 5 and 7, and only in winter on farm No. 6.

During the first four years, the most popular product for oestrus synchronization was the "Eazy-bred" vaginal implant (produced in New Zealand), but since 2005 new purchases were not possible because of EU regulations. The vaginal sponge (Chrono-Gest) was used on the farms over the last 5 years of the studied period. There were significant differences among the farms in the size of PMSG dose. For example, on farm No. 1, 750 IU was administered in the first two years and 600 IU in the following years. 500 IU PMSG dose was 
used on farms No. 5, 6 and 7. On farm No. 10, 550 IU was utilised during the first three years, but because of too strong effects the dose was reduced to 425 IU over the last four years of the studied period.

\subsection{Collecting and examining the semen}

The semen was collected locally on most of the farms by the shepherd with appropriate skills, except for farm No. 8 where transported semen was used. Artificial insemination was carried out by the skilled shepherd, except for farm No. 1, where it was done by a veterinarian in the first two years and by a technician during the following years (Figure 1). Visual examination of the semen was performed before use on every farm, but three (No. 2, 6 and 11) out of the 11 farms used only this method. Following the visual study, microscopic and morphological examinations of the semen were also carried out on farms No. 1 and 7. Microscopic examination of semen together with the visual study was performed on the other six farms.

\subsection{Diluting of semen}

Several kinds of extenders are available for every day use, and in many studies, it has been demonstrated that the use of diluting liquids could help the survival of spermatozoa in the semen. Nevertheless, most shepherds thought that using un-diluted semen produced better results and was safer. Six (No. 2, 3, 4, 5, 9 and 11) out of the eleven farms did not use any kind of extender to dilute the semen before insemination. The 1:2 and 1:4 diluting ratios were used on the first farm and in the first three years on farm No. 10, where a 1:3-diluting ratio was used during the following three years. The 1:4 ratio was used on farm No. 5 (in 2003) and 1:8 on farms No. 6 and 7.

In the 1950s and 60s, one of the most popular extender was skimmed cow milk on farms. However, the Ivanov and the Salamon kinds as well as their improved versions were available after the late 60s and most of the shepherds carrying out the inseminations knew all of them and heard about several other ones. It was particularly interesting because more than half of the shepherds successfully participated in the AI courses mentioned above, and a few were even performing $\mathrm{AI}$ in cattle.

Three of the farms (6, 7 and 8) employed a special extender developed by the research station (farm No. 7). Semen diluted with this extender and cooled and kept at 2 to $4^{\circ} \mathrm{C}$ could be used successfully for 72 hours after collection. The improved Salamon kind of extender was used on farms No. 1 and 10.

\subsection{Semen dose for insemination}

In general, $0.2 \mathrm{ml}$ was the most common dose of inseminating semen. It was used on seven (No. 1, 2, 3, 4, 5, 7 and 8) out of the 11 farms. Doses of 0.1 and $0.3 \mathrm{ml}$ were used on farms No. 9 and 11, as well as No. 6 and 10, respectively.

\subsection{Detecting ewes on heat for insemination}

As the one of the most important factors of successful artificial insemination is selecting the ewes on heat, morning and afternoon selections were used on most farms (No. 1, 3, 4, 5 and 8). The selection was either only performed in the morning (No. 2, 7 and 9) or in the afternoon (No. 6 and 10) on the other farms. Midday was the selection time on farm No. 11 for the first 4 years, which was changed to the morning system during the following years. 
The selection lasted half an hour to one hour during each part of the day. Vasectomised rams were used on farms No. 1 and 7 over the whole studied period. Entire rams with apron were used as teasing rams on five farms (No. 3, 4, 6, 9 and 10) and both kinds of rams were used on only one farm (No. 5). On farm No 2 and 8, vasectomised rams were used in the first four years, and entire rams with apron during the second four years, while on farm No. 11, the order was the reverse: the vasectomised rams were used in the second four years of the period.

\subsection{The time and number of insemination}

Two inseminations were used on most of the farms (No. 1, 2, 3, 4, 5, 6, 7 and 8) about 8 to 10 hours apart (morning-afternoon or afternoon-morning), but only one insemination was utilised on two farms (No. 9 in the morning and No. 11 in the afternoon). On farm No. 10, three inseminations (morning - afternoon - morning or afternoon - morning - afternoon) were carried out each year.

\subsection{Performing insemination}

For successful insemination, ewes have to be fixed and the rear part of their body should be lifted up. The rear legs of the ewes were lifted up and fixed by one labourer on the top of the barrier (Figure 3) in almost all of the studied farms. Farms No. 6 and 8 were the exceptions, where the labourer had to lift up the rear part of the ewes and hold them during the time of insemination.

This operation needs more than one labourer, therefore, one catcher and one inseminator should be used for this job as a minimum. On most of the farms, the inseminations were performed by the owner shepherd with one or two labourers to help him. On farms No. 1 and 7 , technicians conducted the inseminations. There was only one catcher helping the inseminator on farms No. 5, 7, 9, 10 and 11. Two labourers caught and held the ewes on four farms (No. 3, 4, 6 and 8). On the first farm, 5 catchers helped the work of 2 inseminators during the first three years, and in the following two years only one inseminator with two labourers performed the job. On farm No. 2, the number of catchers decreased from two to one during the last three years and only one inseminator worked there.

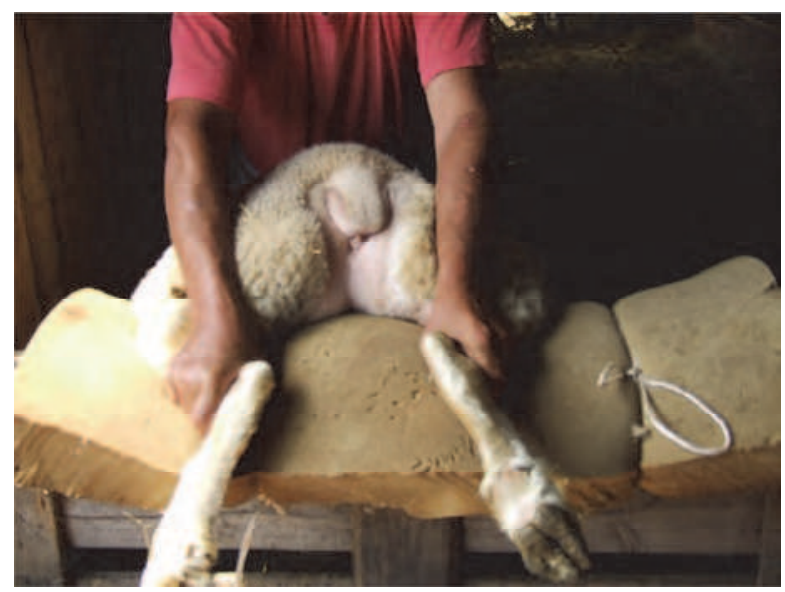

Fig. 3. The fixing of ewe for insemination (Photo: Kukovics, S.) 


\subsection{The place of semen deposition}

The place of semen deposition is the other rather critical point of insemination. Traditional vaginal insemination was used on only one farm (No. 9) and only in the first three years of the studied period. They then changed to cervical deposition. Cervico-uterinal insemination was performed on farms No. 6, 7 and 10 (and sometimes on 11), while cervical insemination was used on other farms (Figure 4). Laparoscopic insemination was only used at the experimental level in the country. It was too expensive for farm practice.

Inseminating pipettes were available on all farms. The special catheter (Figure 1) for transcervical insemination developed by Tassy and Gergatz (Kukovics, 1974) were also used, which was utilised by most inseminators during the studied period. This catheter has a special bent tip that allows passage through the cervix and is made in different sizes for adult ewes and yearlings.

\subsection{The pregnancy control}

The results of lambing were too late to determine the effectiveness of artificial insemination. "State-of-the-art" pregnancy tests to determine the results of AI are important for profitable sheep farming. Yet, the level of pregnancy control in the case of inseminated ewes was rather low on the studied farms. The most up-to-date trans-rectal ultrasonography was used only on farm No. 1. Ultrasonography was performed within 60 days of AI in every studied year on farm No. 10, in the first 4 years on farm No. 7 and only in the first two years on farm No. 5 .

The commonly used method to reach and keep pregnancy at the highest possible level was the post-mating with entire rams that started one cycle after the AI and lasted for two cycles. Farm No. 4 was an exception, where no post-mating was utilised. An interesting thing happened in the case of farm No. 7, where post-mating was not used during the second four years of the studied period.

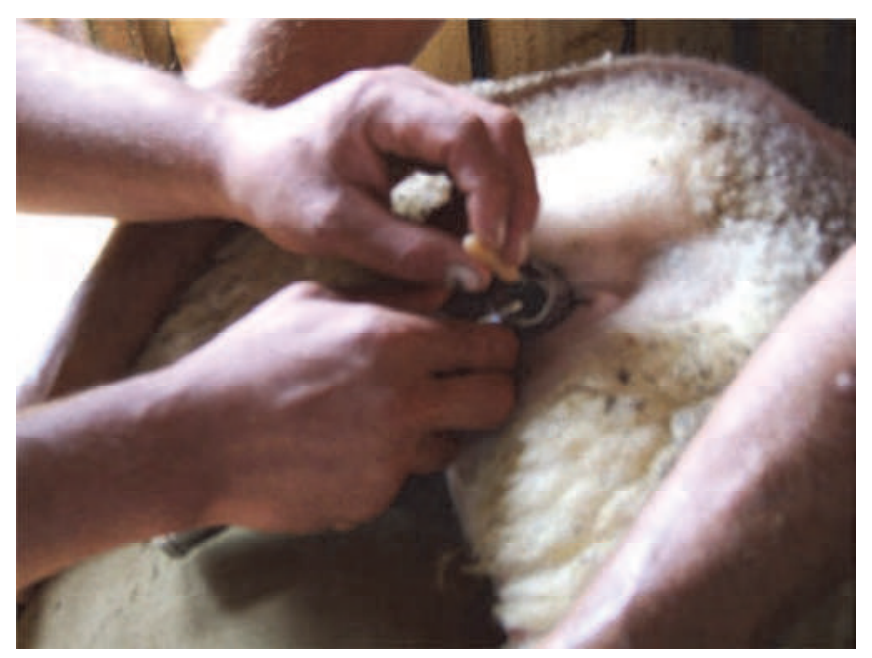

Fig. 4. The insemination (Photo: Kukovics, S.) 


\subsection{The results of artificial insemination}

There were significant differences found among the studied farms and among the various breeds kept on various farms and also between the breeds within the farms. The pregnancy rate in general exceeded $80 \%$ and results over $90 \%$ were not exceptional at all. However, effects of farm, breed and year were observed on the results.

At least two or three breeds were kept on four farms (No. 2, 8, 10 and 11) and only one breed was bred on the other seven farms. Due to this, the results found in the case of four farms were evaluated separately, and the findings concerning the other seven farms were pooled together.

The pregnancy, lambing and weaning rate of the lambs were evaluated and the results are presented in the Tables from 4 to 10 .

\subsubsection{Farms breeding more than one breed}

The pregnancy rate $(\mathrm{P} \%)$ on farm No. 2 was different among breeds in 2004, where Suffolk ewes had a significantly lower value than the other two breeds (Table 4). In 2006, the pregnancy rate of Ile de France ewes was significantly higher than that of the other breeds. In 2005, 2008 and 2009, there were significant differences among all three breeds. In the Bábolna Tetra breed, the highest P\% was measured in 2009, which was significantly higher than in the other years (except 2005 and 2010). The P\% in 2008 was significantly lower than in the other years. In the Ile de France breed, the lowest P\% in 2009 was different from the other values, like the values in 2007 and 2008. In the Suffolk breed, the P\% of 2009 was significantly lower than in the other years (Table 4).

Significant effects of year were observed within the breeds in this trait, more than a $16 \%$ range was found between the smallest and highest values in all three breeds; however, the biggest deviations were in the case of the Suffolk breed.

The lambing rate (L\%) in the Bábolna Tetra breed varied between 1.6 and 2.0, while in Ile de France, the interval was narrower (between 1.2 and 1.4). In the case of the Suffolk breed, the L\% changed every year (Table 4). It meant that the effect of the year was stronger in the Bábolna Tetra and Suffolk breeds than in the Ile the France. However, the differences reached the significant level $(\mathrm{P}<5.0 \%)$ only between 2007 and 2009 and between 2004 and 2007 in the case of the first two years, respectively. Given that the lambing rate was a steady characteristic of the breeds, the comparison of these breeds was not justified (Table 4).

Breed and the year effect were equally found in the case of the weaning rate. Regarding the year effect, the smallest distance was observed in the case of Ile de France (less than 10\%) and the biggest in Suffolk (more than 19\%). The rate was 15.6\% in the Bábolna Tetra breed.

The weaning \% had an increasing trend from Bábolna Tetra to Suffolk via Ile de France in $2004,2008,2009$, and the opposite trend was found in 2003. In the other years, the ranking of the breeds changed. The highest weaning \% was measured in 2009 in the case of Bábolna Tetra $(97.8 \%)$, while the most successful year was 2005 for the Ile de France and Suffolk breeds (91.1 and 93.2\%, respectively). The weakest result in Bábolna Tetra was found in $2003(82.2 \%)$, while this happened for Ile de France in 2010 (81.1\%) and 2007 for the Suffolk $(68.4 \%)$ breed. In most cases, there were significant differences among the data (Table 4).

Among the breeds kept on farm No. 9, the only differences were observed in 2004 and 2006, when the pregnancy rate of German Blackheaded Mutton was significantly lower than that of the other two breeds (Table 5).

In the Hungarian Merino breed, the P\% of 2006 differed from those of the other years (except 2010), which differed from other previous years. In the German Mutton Merino 
breed, the data of 2006 differed from that of 2003, 2005 and 2007. In the German Blackheaded Mutton breed, there were no significant differences between 2003 and 2006 and from 2005 to 2010 (Table 5).

\begin{tabular}{|c|c|c|c|c|c|c|c|c|c|}
\hline \multirow{2}{*}{$\begin{array}{c}\text { Breed, } \\
\text { trait, } \\
\text { year }\end{array}$} & \multicolumn{3}{|c|}{ Bábolna Tetra } & \multicolumn{3}{c|}{ Ile de France } & \multicolumn{3}{c|}{ Suffolk } \\
\cline { 2 - 10 } & $P \%$ & $L \%$ & $W \%$ & $\mathrm{P} \%$ & $\mathrm{~L} \%$ & $\mathrm{~W} \%$ & $\mathrm{P} \%$ & $\mathrm{~L} \%$ & $\mathrm{~W} \%$ \\
\hline 2003 & $82.2^{\mathrm{aA}}$ & 1.7 & $82.2^{\mathrm{aA}}$ & $81.4^{\mathrm{aA}}$ & 1.2 & $85.8^{\mathrm{bcA}}$ & $76.9^{\mathrm{aA}}$ & 1.4 & $86.4^{\mathrm{acA}}$ \\
\hline 2004 & $86.1^{\mathrm{aB}}$ & 1.8 & $86.0^{\mathrm{aB}}$ & $83.3^{\mathrm{aA}}$ & 1.3 & $84.3^{\mathrm{acAC}}$ & $73.9 \mathrm{bAB}$ & 1.7 & $79.9 \mathrm{bcA}$ \\
\hline 2005 & $87.3^{\mathrm{aBE}}$ & 1.7 & $94.2^{\mathrm{aC}}$ & $90.4^{\mathrm{bB}}$ & 1.3 & $91.1^{\mathrm{bcB}}$ & $66.3^{\mathrm{cB}}$ & 1.5 & $93.2^{\mathrm{acB}}$ \\
\hline 2006 & $79.4^{\mathrm{aC}}$ & 1.7 & $83.7^{\mathrm{aA}}$ & $92.2^{\mathrm{bB}}$ & 1.2 & $88.7 \mathrm{bcAB}$ & $77.4^{\mathrm{aA}}$ & 1.4 & $85.4^{\mathrm{acA}}$ \\
\hline 2007 & $79.7^{\mathrm{aAC}}$ & 1.6 & $88.5^{\mathrm{aD}}$ & $79.6^{\mathrm{aA}}$ & 1.3 & $87.1^{\mathrm{aA}}$ & $80.4^{\mathrm{aA}}$ & 1.2 & $68.4^{\mathrm{bC}}$ \\
\hline 2008 & $73.1^{\mathrm{aD}}$ & 1.7 & $84.4^{\mathrm{aAB}}$ & $94.6^{\mathrm{bC}}$ & 1.3 & $83.3^{\mathrm{aAC}}$ & $79.6^{\mathrm{cA}}$ & 1.4 & $81.8^{\mathrm{aA}}$ \\
\hline 2009 & $90.7^{\mathrm{aE}}$ & 2.0 & $97.8^{\mathrm{aDE}}$ & $84.7^{\mathrm{bD}}$ & 1.2 & $87.9^{\mathrm{aAD}}$ & $85.7 \mathrm{C}$ & 1.3 & $86.9^{\mathrm{aAD}}$ \\
\hline 2010 & $86.7^{\mathrm{aABE}}$ & 1.9 & $82.3^{\mathrm{aA}}$ & $90.3^{\mathrm{aB}}$ & 1.4 & $81.8^{\mathrm{aA}}$ & $83.2^{\mathrm{aA}}$ & 1.5 & $82.1^{\mathrm{aA}}$ \\
\hline
\end{tabular}

The different small letters in rows and the different upper case letters in columns mean significant differences $(P \leq 0.05)$ per trait (pregnancy, weaning) among breeds and years.

Table 4. The result of AI on farm No. 2

The lambing rate (\%) in Hungarian Merino varied between 1.5 and 1.7, while it was between 1.6 and 1.8 in German Mutton Merino. In German Blackheaded Mutton sheep, the lowest rate was 1.5 in 2009, while the highest 1.8 value was found four times (Table 5). The value of this trait exceeded the national average by 0.3 to 0.4 lambs in the case of Hungarian Merino. Additionally, German Mutton Merino and German Blackheaded Mutton sheep had a 0.2 to 0.3 advantage per lambing over the national average in the country.

\begin{tabular}{|l|l|l|l|l|l|l|l|l|l|}
\hline \multirow{2}{*}{$\begin{array}{l}\text { Breed, } \\
\text { trait, } \\
\text { year }\end{array}$} & \multicolumn{3}{|c|}{ Hungarian Merino } & \multicolumn{3}{|c|}{ German Mutton Merino } & \multicolumn{3}{c|}{$\begin{array}{c}\text { German Blackheaded } \\
\text { Mutton Sheep }\end{array}$} \\
\cline { 2 - 10 } & $\mathrm{P} \%$ & $\mathrm{~L} \%$ & $\mathrm{~W} \%$ & $\mathrm{P} \%$ & $\mathrm{~L} \%$ & $\mathrm{~W} \%$ & $\mathrm{P} \%$ & $\mathrm{~L} \%$ & $\mathrm{~W} \%$ \\
\hline 2003 & $89.5^{\mathrm{aA}}$ & 1.6 & $96.4^{\mathrm{aA}}$ & $92.2^{\mathrm{aA}}$ & 1.7 & $95.9^{\mathrm{aA}}$ & $87.9^{\mathrm{aA}}$ & 1.8 & $96.7^{\mathrm{aA}}$ \\
\hline 2004 & $92.4^{\mathrm{aAC}}$ & 1.6 & $97.4^{\mathrm{aA}}$ & $3.9^{\mathrm{aAB}}$ & 1.6 & $96.7^{\mathrm{aA}}$ & $85.5^{\mathrm{bA}}$ & 1.7 & $95.4^{\mathrm{aA}}$ \\
\hline 2005 & $90.4^{\mathrm{aAC}}$ & 1.7 & $97.2^{\mathrm{aA}}$ & $93.1^{\mathrm{aA}}$ & 1.7 & $96.6^{\mathrm{aA}}$ & $91.8^{\mathrm{aAC}}$ & 1.8 & $95.3^{\mathrm{aA}}$ \\
\hline 2006 & $97.5^{\mathrm{aB}}$ & 1.5 & $96.6^{\mathrm{aA}}$ & $96.3^{\mathrm{aB}}$ & 1.7 & $95.8^{\mathrm{aA}}$ & $89.9^{\mathrm{bAC}}$ & 1.8 & $94.9^{\mathrm{aA}}$ \\
\hline 2007 & $91.4^{\mathrm{aAC}}$ & 1.7 & $4.9^{\mathrm{aAB}}$ & $92.8^{\mathrm{aA}}$ & 1.6 & $95.0^{\mathrm{aA}}$ & $95.2^{\mathrm{aBC}}$ & 1.8 & $93.0^{\mathrm{aA}}$ \\
\hline 2008 & $93.1^{\mathrm{aC}}$ & 1.7 & $96.3^{\mathrm{aA}}$ & $93.7^{\mathrm{aA}}$ & 1.6 & $95.4^{\mathrm{aA}}$ & $94.4^{\mathrm{aBC}}$ & 1.7 & $94.3^{\mathrm{aA}}$ \\
\hline 2009 & $94.6^{\mathrm{aACD}}$ & 1.7 & $96.6^{\mathrm{aA}}$ & $93.4^{\mathrm{aA}}$ & 1.8 & $95.3^{\mathrm{acA}}$ & $90.7^{\mathrm{aAC}}$ & 1.5 & $93.3^{\mathrm{bcA}}$ \\
\hline 2010 & $96.4^{\mathrm{aB}}$ & 1.6 & $95.1^{\mathrm{aAB}}$ & $93.5^{\mathrm{aA}}$ & 1.7 & $95.3^{\mathrm{aA}}$ & $92.9^{\mathrm{aAC}}$ & 1.7 & $94.6^{\mathrm{aA}}$ \\
\hline
\end{tabular}

The different small letters in rows and the different upper case letters in columns mean significant differences $(P \leq 0.05)$ per trait (pregnancy, weaning) among breeds and years.

Table 5. The results of AI on farm No. 9 
As this farm was one of the best, these data were very close to each other and their levels were close to the maximum of the genetic possibilities, yet the differences found among them originated from the breed characteristics. Of course, the year effects were also observed among these data, but the differences reached the significant level $(\mathrm{P}<5.0 \%)$ in only one case in German Blackheaded Mutton Sheep (2009 vs. 2003, 2005, 2006, 2007), in German Mutton Merino (2009 vs. 2004, 2007, 2008) and in Hungarian Merino (2006 vs. 2005, 2007, 2008, 2009).

In the weaning ratio of the period of 2003 to 2006, there were no significant differences in a breed between years and between breeds by year (Table 5).

In Hungarian Merino, only the ratio in 2004 differed from that of 2007 and 2010. In the other two breeds, there were no significant differences between years (Table 5).

The results from farm No. 10 keeping three different breeds are shown in Table 6.

The pregnancy rate of British Milksheep differed from Hungarian Merino in 2007 and from Charollais in 2009. In 2008, there were no significant differences. In British Milksheep, the pregnancy ratio of 2007 differed from that of 2009, but in the other two breeds, there were no statistical differences among the years (Table 6).

The lambing rate of British Milksheep was the highest among the breeds (between 1.9 and 2.6), while the lowest was in Charollais (between 1.4 and 1.8). In the Hungarian Merino, it varied between 1.5 and 1.7 (Table 6). Since the lambing rate was a steady characteristic of the breeds, the comparison of these breeds was not necessary. At the same time, the year effect was significantly lower in 2009 in British Milksheep compared to the other years and the difference also reached this level between 2007 and 2008. In the case of Charollais, the values of 2009 were significantly higher compared to those of the other two years.

The weaning ratio of British Milksheep differed from that of Hungarian Merino in 2007 and from Charollais in 2009. In 2008, there were no significant differences. In the weaning ratio of British Milksheep lambs, the year 2009 differed from the previous years, except 2008, while 2006 differed from all other years. In the other two breeds there were no statistical differences in weaning ratios among the years (Table 6).

\begin{tabular}{|l|c|c|c|c|c|c|c|c|c|}
\hline \multirow{2}{*}{$\begin{array}{l}\text { Breed, } \\
\text { trait, } \\
\text { year }\end{array}$} & \multicolumn{3}{|c|}{ British Milksheep } & \multicolumn{4}{c|}{ Charollais } & \multicolumn{3}{c|}{ Hungarian Merino } \\
\cline { 2 - 10 } & $\mathrm{P} \%$ & $\mathrm{~L} \%$ & $\mathrm{~W} \%$ & $\mathrm{P} \%$ & $\mathrm{~L} \%$ & $\mathrm{~W} \%$ & $\mathrm{P} \%$ & $\mathrm{~L} \%$ & $\mathrm{~W} \%$ \\
\hline 2005 & $97.0^{\mathrm{A}}$ & 2.5 & $73.4^{\mathrm{A}}$ & - & - & - & - & - & - \\
\hline 2006 & $87.8^{\mathrm{A}}$ & 2.4 & $65.9^{\mathrm{AB}}$ & - & - & - & - & - & - \\
\hline 2007 & $100.0^{\mathrm{aAB}}$ & 2.3 & $81.7^{\mathrm{aAC}}$ & $72.7^{\mathrm{acA}}$ & 1.5 & $100.0^{\mathrm{acA}}$ & $67.8^{\mathrm{bcA}}$ & 1.7 & $91.2^{\mathrm{bcA}}$ \\
\hline 2008 & $89.3^{\mathrm{aA}}$ & 2.6 & $92.3^{\mathrm{aC}}$ & $100.0^{\mathrm{aA}}$ & 1.4 & $81.8^{\mathrm{aA}}$ & $76.0^{\mathrm{aA}}$ & 1.5 & $91.8^{\mathrm{aA}}$ \\
\hline 2009 & $87.8^{\mathrm{aAC}}$ & 1.9 & $97.0^{\mathrm{aC}}$ & $93.8^{\mathrm{bcA}}$ & 1.8 & $85.2^{\mathrm{bcA}}$ & $70.7^{\mathrm{acA}}$ & 1.7 & $9.3^{\mathrm{acA}}$ \\
\hline 2010 & $*$ & $*$ & $*$ & $*$ & $*$ & $*$ & $*$ & $*$ & $*$ \\
\hline
\end{tabular}

The different small letters in rows and the different upper case letters in columns mean significant differences $(P \leq 0.05)$ per trait (pregnancy, weaning) among breeds and years.

*lambing started in 2011

Table 6. The results of AI on farm No. 10

On farm No. 11, there were no significant differences in the years between the two breeds kept in P\%. The pregnancy rate of British Milksheep in 2003 differed significantly from that of the other years. In the British Milksheep Crossbreds, there were no significant differences among the years (Table 7). 
The lambing rate in purebred was higher than that in the crossbred population, varying between 2.0 and 2.4, while in crossbreds, it was between 1.9 and 2.4 (Table 7). In the case of crossbreds, the year 2009 was almost exceptional (P<5.0\%; 2009 vs. 2007 and 2008), while in the case of purebred, the lambing rate of 2010 significantly differed from that of the years 2006 and 2007 (Table 7).

\begin{tabular}{|c|c|c|c|c|c|c|}
\hline \multirow{2}{*}{$\begin{array}{c}\text { Breed, trait, } \\
\text { year }\end{array}$} & \multicolumn{3}{|c|}{ British Milksheep } & \multicolumn{3}{c|}{ British Milksheep Crossbreds } \\
\cline { 2 - 7 } & $\mathrm{P} \%$ & $\mathrm{~L} \%$ & $\mathrm{~W} \%$ & $\mathrm{P} \%$ & $\mathrm{~L} \%$ & $\mathrm{~W} \%$ \\
\hline 2003 & $93.3^{\mathrm{A}}$ & 2.2 & $82.4^{\mathrm{A}}$ & - & - & - \\
\hline 2004 & $88.5^{\mathrm{B}}$ & 2.1 & $87.8^{\mathrm{B}}$ & - & - & - \\
\hline 2005 & $82.9^{\mathrm{CD}}$ & 2.1 & $92.1^{\mathrm{C}}$ & - & - & - \\
\hline 2006 & $87.5^{\mathrm{BD}}$ & 2.0 & $94.9^{\mathrm{CD}}$ & - & - & - \\
\hline 2007 & $78.6^{\mathrm{aCD}}$ & 2.0 & $88.9^{\mathrm{aBC}}$ & $78.6^{\mathrm{aA}}$ & 1.9 & $98.0^{\mathrm{bA}}$ \\
\hline 2008 & $83.3^{\mathrm{aBD}}$ & 2.1 & $94.1^{\mathrm{aCD}}$ & $83.3^{\mathrm{aA}}$ & 2.0 & $93.9^{\mathrm{aA}}$ \\
\hline 2009 & $83.0^{\mathrm{aBC}}$ & 2.3 & $96.7^{\mathrm{aD}}$ & $75.0^{\mathrm{aA}}$ & 2.4 & $98.2^{\mathrm{aA}}$ \\
\hline 2010 & $85.7^{\mathrm{BC}}$ & 2.4 & $98.4^{\mathrm{D}}$ & $*$ & $*$ & $*$ \\
\hline
\end{tabular}

The different small letters in rows and the different upper case letters in columns mean significant differences $(P \leq 0.05)$ per trait (pregnancy, weaning) among breeds and years.

*lambing started in 2011

Table 7. The results of AI on farm No. 11

The weaning ratio of British Milksheep only differed from that of British Milksheep Crossbred in 2007. In British Milksheep, the ratio of weaned lambs in 2003 was significantly different from that of the other years, and 2010 from all other years. In British Milksheep Crossbred, there were no significant differences among the years (Table 7).

\subsubsection{Farms with only one breed}

Among the inseminating farms with one breed only, the Awassi farm's P\% was significantly different among the years, except between 2003 and 2004. On farm No. 3, the lower pregnancy rate was found in 2005, which differed significantly from the other years, while only the values from 2003 and 2006 did not differ from each other.

On the P\% on farm No. 5, the year 2005 was different from the other years. On farm No. 4, the values received from 2008 differed from those of 2005 and 2006. On farm No. 7, the rate in 2004 differed from that of 2003, 2006 and 2007, the value of 2005 was different from that of 2003, the rate of 2006 differed from 2007, and that of 2006 was different from those of 2004, 2005, 2008 and 2009. On farm No. 8, the P\% was not significantly different from each other (Table 8).

The lambing rate of Awassi breed was steady at 1.3, the lowest among the breeds, and no year effects were observed. Small differences were found between the two Hungarian Merino populations, and the values of the "better one" sharply decreased over the last two years because of labour problem. German Mutton Merino had a constant lambing rate. In the Lacaune breed, the lambing rate varied between 1.4 and 1.6 on the three farms (Table 9), and minimal effects of year were observed in the case of farm No. 7. 


\begin{tabular}{|c|c|c|c|c|c|c|c|c|}
\hline $\begin{array}{c}\text { Farm } \\
\text { code }\end{array}$ & breed / year & 2003 & 2004 & 2005 & 2006 & 2007 & 2008 & 2009 \\
\hline 1 & $\begin{array}{c}\text { Awassi+Awassi } \\
\text { crossbreds }\end{array}$ & $37.3^{\mathrm{a}}$ & $35.0^{\mathrm{a}}$ & $45.0^{\mathrm{b}}$ & $56.8^{\mathrm{c}}$ & $80.0^{\mathrm{d}}$ & - & - \\
\hline 3 & Hungarian Merino & $83.2^{\mathrm{a}}$ & $93.4^{\mathrm{b}}$ & $67.0^{\mathrm{c}}$ & $83.0^{\mathrm{a}}$ & - & - & - \\
\hline 5 & Hungarian Merino & $75.0^{\mathrm{a}}$ & $67.5^{\mathrm{ac}}$ & $78.6^{\mathrm{ab}}$ & $62.9^{\mathrm{bc}}$ & $66.7^{\mathrm{a}}$ & $61.5^{\mathrm{acd}}$ & - \\
\hline 4 & $\begin{array}{c}\text { German Mutton } \\
\text { Merino }\end{array}$ & $84.4^{\mathrm{a}}$ & $83.8^{\mathrm{a}}$ & $87.0^{\mathrm{ab}}$ & $86.7^{\mathrm{a}}$ & $84.3^{\mathrm{a}}$ & $81.0^{\mathrm{ac}}$ & - \\
\hline 6 & Lacaune & - & - & - & - & - & - & 88.2 \\
\hline 7 & Lacaune $^{*}$ & $95.3^{\mathrm{a}}$ & $85.2^{\mathrm{b}}$ & $81.8^{\mathrm{b}}$ & $96.7^{\mathrm{a}}$ & $97.6^{\mathrm{a}}$ & $82.7^{\mathrm{b}}$ & $79.6^{\mathrm{b}}$ \\
\hline 8 & Lacaune & $58.6^{\mathrm{a}}$ & $66.1^{\mathrm{a}}$ & - & - & - & - & - \\
\hline
\end{tabular}

The different small letters in rows indicate significant differences $(P \leq 0.05)$.

*The lambing after AI made in 2010 started in 2011

Table 8 . The pregnancy rate (\%) on farms with one breed

\begin{tabular}{|c|c|c|c|c|c|c|c|c|}
\hline $\begin{array}{c}\text { Farm } \\
\text { code }\end{array}$ & breed / year & 2003 & 2004 & 2005 & 2006 & 2007 & 2008 & 2009 \\
\hline 1 & $\begin{array}{c}\text { Awassi, Awassi } \\
\text { crossbreds }\end{array}$ & 1.3 & 1.3 & 1.3 & 1.3 & 1.3 & - & - \\
\hline 3 & Hungarian Merino & 1.4 & 1.3 & 1.3 & 1.4 & - & - & - \\
\hline 5 & Hungarian Merino & 1.5 & 1.5 & 1.5 & 1.4 & 1.2 & 1.2 & - \\
\hline 4 & $\begin{array}{c}\text { German Mutton } \\
\text { Merino }\end{array}$ & 1.4 & 1.4 & 1.4 & 1.4 & 1.5 & 1.5 & - \\
\hline 6 & Lacaune* & - & - & - & - & - & - & 1.5 \\
\hline 7 & Lacaune* & 1.4 & 1.6 & 1.5 & 1.6 & 1.5 & 1.4 & 1.6 \\
\hline 8 & Lacaune & 1.6 & 1.6 & - & - & - & - & - \\
\hline
\end{tabular}

*The lambing after AI made in 2010 started in 2011

Table 9. The lambing rate (\%) on farms with one breed

\begin{tabular}{|c|c|c|c|c|c|c|c|c|}
\hline $\begin{array}{c}\text { Farm } \\
\text { code }\end{array}$ & breed / year & 2003 & 2004 & 2005 & 2006 & 2007 & 2008 & 2009 \\
\hline 1 & $\begin{array}{c}\text { Awassi, Awassi } \\
\text { crossbreds }\end{array}$ & $94.5^{\mathrm{a}}$ & $95.3^{\mathrm{a}}$ & $94.8^{\mathrm{a}}$ & $95.6^{\mathrm{a}}$ & $96.2^{\mathrm{a}}$ & - & - \\
\hline 3 & Hungarian Merino & $96.6^{\mathrm{a}}$ & $91.3^{\mathrm{bd}}$ & $86.5^{\mathrm{cd}}$ & $90.5^{\mathrm{d}}$ & - & - & - \\
\hline 5 & Hungarian Merino & $88.0^{\mathrm{a}}$ & $89.8^{\mathrm{a}}$ & $95.6^{\mathrm{b}}$ & $97.4^{\mathrm{b}}$ & $84.1^{\mathrm{ac}}$ & $90.9^{\mathrm{abc}}$ & - \\
\hline 4 & $\begin{array}{c}\text { German Mutton } \\
\text { Merino }\end{array}$ & $89.3^{\mathrm{a}}$ & $89.0^{\mathrm{a}}$ & $89.3^{\mathrm{ab}}$ & $90.9^{\mathrm{a}}$ & $87.0^{\mathrm{ac}}$ & $88.3^{\mathrm{a}}$ & - \\
\hline 6 & Lacaune* & - & - & - & - & - & - & 95.2 \\
\hline 7 & Lacaune $^{*}$ & $53.0^{\mathrm{a}}$ & $86.5^{\mathrm{b}}$ & $84.8^{\mathrm{b}}$ & $80.3^{\mathrm{b}}$ & $85.5^{\mathrm{b}}$ & $79.7^{\mathrm{bc}}$ & $71.2^{\mathrm{c}}$ \\
\hline 8 & Lacaune $^{\mathrm{a}}$ & $89.8^{\mathrm{a}}$ & $93.9^{\mathrm{a}}$ & - & - & - & - & - \\
\hline
\end{tabular}

The different small letters in rows indicate significant differences $(P \leq 0.05)$.

*The lambing after AI made in 2010 started in 2011

Table 10. The weaning rate (\%) on farms with one breed 
In the Awassi breed, there were no significant differences among years in the weaning rate. On farm No. 3, the W\% was the highest in 2003, which was significantly different from the other studied years. However, the ratio in 2006 was close to the values found in 2004 and 2005. On farm No. 5, 2006 was the year most different from the others. On farm No. 4, the only difference observed was between 2006 and 2007, while on No. 7, the two terminal years (2003 and 2009) differed from the other years. On farm No. 8, there was no significant difference among years in the weaning rate (Table 10).

\subsection{The cost of artificial insemination}

Rather big differences were observed among the studied farms (Table 11). In most cases, these data were calculated by the owner of the farm and mainly covered the direct cost of semen collection and insemination, while other costs were not included. On some farms, the same level was calculated every year, while on others, the annual costs increased with the years. Apart from these, the use of oestrus synchronisation increased the costs by about 7 or above 8 euros per ewe.

In general, the average direct costs of artificial insemination per ewe could reach 0.4 to 0.5 euros, and in the case of oestrus synchronisation, the total costs could exceed 7 to 8 euros under present Hungarian circumstances.

\begin{tabular}{|c|c|c|c|c|c|c|c|c|}
\hline $\begin{array}{c}\text { Farm } \\
\text { code }\end{array}$ & 2003 & 2004 & 2005 & 2006 & 2007 & 2008 & 2009 & 2010 \\
\hline 1 & $3.70^{*}$ & $3.70^{* *}$ & $3.70^{* *}$ & $3.70^{* *}$ & $5.56^{* *}$ & - & - & - \\
\hline 2 & 0.74 & 0.74 & 0.74 & 0.74 & 0.74 & 0.74 & 0.74 & 0.74 \\
\hline 3 & 1.48 & 1.67 & 1.85 & 1.85 & - & - & - & - \\
\hline 4 & $0.37^{*}$ & $0.37^{*}$ & $0.37^{*}$ & $0.37^{*}$ & $0.37^{*}$ & $0.37^{*}$ & - & - \\
\hline 5 & 0.74 & 0.74 & 0.93 & 1.11 & 1.11 & 1.31 & - & - \\
\hline 6 & - & - & - & - & - & - & $0.37^{*}$ & $0.37^{*}$ \\
\hline 7 & 3.70 & 3.70 & 3.70 & $3.70^{*}$ & $3.70^{*}$ & $3.70^{* *}$ & $3.70^{* *}$ & $3.70^{* *}$ \\
\hline 8 & 0.93 & 1.11 & 1.30 & 1.30 & 1.30 & 1.85 & 1.85 & 1.85 \\
\hline 9 & 1.85 & 1.85 & - & - & - & - & - & - \\
\hline 10 & - & - & $0.37^{*}$ & $0.37^{*}$ & $0.37^{*}$ & $0.37^{*}$ & $0.37^{*}$ & $0.37^{*}$ \\
\hline 11 & & 0.37 & 0.37 & 0.37 & 0.37 & 0.37 & 0.37 & 0.37 \\
\hline
\end{tabular}

It was calculated on the changing rate of 1 euro $=270 \mathrm{HUF}$

In the case of oestrus synchronisation, the costs reached seven $\left({ }^{*}\right)$ or eight euros $\left({ }^{* *}\right)$ per ewe.

Table 11. The estimated costs of artificial insemination (euro/ewe)

\section{Conclusions}

Apart from the fact that artificial insemination is used only on a limited number of Hungarian sheep farms, the effectiveness of this method was quite reasonable. Based on the results, the following conclusions can be drawn.

- Apart from the lack of officially-organised education of shepherds, there are some sheep owners and shepherds who can operate with the method of artificial insemination at a very good level (Kukovics \& Gergazt, 2009). 
- Artificial insemination of ewes can be performed with very high effectiveness on farms in every day practice mainly by shepherds. The reality is that AI does not need veterinary assistance, but maintaining the health of ewes needs veterinary control.

- The procedure of artificial insemination requires well-skilled shepherds with good practice and enough support.

- The breed of ewe has a significant effect on the pregnancy rate, which is consistent with the results of Hill et al. (1998), Perkins et al. (1996), Donovan et al. (2001 and 2004), Karagiannidis et al. (2001) and Anel et al. (2005). However, the results could be positively modified by the interest of the sheep owner.

- The dose of PMSG affected conception rate, similar to the findings of Hill et al. (1998). Thus, in some cases, the dose should be reduced in order to avoid too many lambs being born and higher lamb loss originating from the weakness of the lambs at birth.

- Most shepherds use fresh, locally collected, un-diluted semen with good results, and the importance of dilution is only realised by a small number of the shepherds.

- The year had a strong effect on the results of artificial insemination, in accordance with the results of Anel et al. (2005), but no trends could be discovered in the data. The environmental circumstances (available pasture and feed for instance) had stronger importance.

- The cost of artificial insemination depends on the farm, but in general, the direct cost was less than one euro per ewe. Of course, in the case of oestrus synchronisation and induction, these costs could reach 7 to 8 euros per ewe.

- The results of artificial insemination could easily be controlled by using ultrasonography (Egerszegi at al., 2008) at an early stage of pregnancy, but this method was only used on a small number of farms.

\section{Acknowledgements}

The authors would like to thank the owners and the representatives of the sheep farms for their excellent technical help in collecting the data and analysing the information needed for final evaluation. They are in alphabetic order: Attila Harcsa (Abbod Farm, Szendrő), Antal Kádas (Túrkeve), István Nagy and Imre Nagy (Ganna), László Nagy (Eger), Sándor Nagy (Bakonszeg Awassi Corporation, Bakonszeg), Zoltán Nagy (Harkakötöny), Mihály Sebók (Törtel), Ede Sipos (Móriczhida), Károly Szabó (Hajdúbagos) and Zoltán Szabó (Karcag).

The study was made by K-OVI-CAP BT within the framework of University of Debrecen Centre of Agriculture and Economic Sciences with the help of the Jedlik Ányos project supported by National Office of Research and Technology (NKTH)

\section{References}

Anel, L., M. Kaabi, B. Abroug, M. Alvarez, E. Anel, J.C. Boixo, L.F. de la Fuente, P. De Paz (2005). Factors influencing the success of vaginal and laparoscopic artificial insemination in Churra ewes: a field assay, Theriogenology, 63, 1235-1247.

Barillet, F., S., Sanna, D., Boichard, J.M., Astruc, A., Carta, S., Casu (1993). Genetic evaluation of the Lacaune, Manech and Sarda dairy sheep with Animal Model, Proceedings of 5th International Symposium on Machine Milking of Small Ruminants /Ed.: Kukovics, S./, Hungary, May 1993, 289-303. 
Becze, J. (1982). Tanulmányok haszonállatok szaporításáról. (Studies on the reproduction of domestic animal breeds); Mezőgazdasági Kiadó, ISBN 963-231-114-0, Budapest

Donovan, A. , J.P. Hanrahan, T. Lally, M.P. Boland, G. P. Lonergan, D.J. O’Neil (2001). AI for sheep using frozen-thawed semen, ARMIS 4047 Project report, under the Research Stimulus Fund; OPARDF measure 5b, ISBN 1841701521

Donovan, A. , J.P. Hanrahan, E. Kummen, P. Duffy, M.P. Boland (2004). Fertility of the ewe following cervical insemination with fresh or frozen-thawed semen at natural or synchronised oestrus, Animal Reproduction Science, 84, 359-368.

Egerszegi, I., A., Molnár, P., Sarlós, F., Soós, J., Rátky (2008). Investigation of the follicular development and early Pregnancy in Hungarian Black Racka ewes by means ultrasonography - preliminary study (A tüszőnövekedés és korai vemhesség ultrahangos vizsgálata fekete racka juhokban - előkísérlet) AWETH 4. (2.) 311-318. 2008 I. Gödöllői Állattenyésztési Tudományos Napok, Gödöllő 12-13, (in Hungarian)

Ehling, C., P. Wirth, L. Schindler, K.-G. Hadeler, H.-H. Döpke, E. Lemme, D. Herrmann, H. Niemann (2003). Laparoscopical intrauterine insemination with different doses of fresh, conserved, and frozen-thawed semen for the production of ovine zygotes, Theriogenology, 60, 777-787.

Fernandez-Abella, D., M.O. Preve, N. Villegas (2003). Insemination time and diluting rate of cooled and chilled ram semen affects fertility, Theriogenology, 60, 21-26.

Gergátz, E. (2007). A juhok mesterséges termékenyítése; in: Házi emlősállatok mesterséges termékenyítése. (The artificial insemination in sheep; in Artificial insemination in domestic mammals); Szerk. (Edited) Tamás Pécsi; Pécsi Tamás, Mezőgazda Kiadó,Bp. ISBN 978-963-286-237-8

Gergátz, E., E., Gyökér (1997). Cervicouterinal Insemination method with cooled and deep frozen ram semen; 48. Annual Meeting of EAAP,Vienna, Book of Abstract, 319-325.

Gulyás, L., E., Gergátz, J., Végh, A., Németh (2007). A fogyasztási csúcsokhoz igazodó bárányelőállítás lehetőségei biotechnikai módszerek felhasználásával. (Possibilities of lamb meat production adjusted to consuming peaks using biotechnical methods). Acta Agronomica Óváriensis 49. 1.-29-42.

Hill, J. R., J. A., Thomson, N.R., Perkins (1998). Factors affecting pregnancy rates following laparoscopic insemination of 28,447 Merino ewes under commercial conditions: a survey, Theriogenology, 49, 697-709.

Jávor, A., S., Kukovics, Gy. Molnár (2006). Juhtenyésztés A-tól Z-ig (Sheep breeding to A to Z), Mezőgazda Kiadó, ISBN 963286275 9, Budapest.

Karagiannidis, A., S. Varsakeli, G. Karatzas, C. Brozos (2001). Effect of time of artificial insemination on fertility of progestegen and PMSG treated indigenous Greek ewes, during non-breeding season, Small Ruminant Research, 39, 67-71.

King, M.E., W.A.C. McKelvey, W.S. Dingwall, K.P. Matthews, F.E. Gebbie, M.J.A. Mylne, E. Stewart, J.J. Robinson (2004). Lambing rates and litter sizes following intrauterine or cervical insemination of frozen-thawed semen with or without oxytocin administration, Theriogenology, 62, 1236-1244.

Kukovics, S. (1974). A mesterséges termékenyítés eredményeinek értékelése, valamint a juh szaporaságának és gazdaságosságának néhány kérdése (The evalation of the results of artificial insemination and some questions prolificacy and profitability in 
sheep); Állattenyésztési Kutatóintézet (Research Institute for Animal Production) Herceghalom, research study report made for Ministry of Agriculture, p. 120.

Kukovics, S., E. Gergatz (2009). A juh mesterséges termékenyítése üzemekben (Artificial insemination of sheep on farm), In: Magyar Állatorvosok Lapja (Hungarian Veterinary Journal), 131, 21-26.

Kukovics, S., A., Jávor (2002). A világfajták szerepe a juh árutermelésben. (The role of world sheep breeds in commodity production), Magyar Juhászat + Kecsketenyésztés (Hungarian Sheep Farming + Goat Breeding), Vol. 11, No. 11, pp. 4-8.

Moses, D., A.G., Martinez, G., Iorio, A., Valcárcel, A., Ham, H., Pessi, R., Castanon, A., Maciá, M.A. de las Heras (1997). A large-scale program in laparoscopic intrauterine insemination with frozen-thawed semen in Australian Merino sheep in Argentine Patagonia, Theriogeneology, 48, 651-657.

Mucsi, I. (1997). Juhtenyésztés és - tartás (Sheep breeding and keeping), Mezőgazda Kiadó, ISBN 963912124, Budapest.

Perkins, N.R., J.R. Hill, R.G. Pedrana (1996). Laparoscopic insemination of frozen-thawed semen into one or bothuterine horns without regard to ovulation site in synchronised Merino ewes, Theriogenology, 46, 541-545.

Salamon, S., W.M.C. Maxwell (1995). Frozen storage of ram semen. I. Processing, freezing, thawing and fertility after cervical insemination, Animal Reproduction Science, 37, 185-249.

Sarlós, P. (1999). Kosspermatermelés, kosspermaminőség (Production of ram semen, quality of ram semen), Állattenyésztési és Takarmányozási Kutatóintézet, Herceghalom, Retrieved from <http://www.atk.hu/Magyar/Ubbs/juhtart/index.html>

Stefanov, R., E., Krumova, M., Dolashka, W., Voelter, Z., Zachariev (2006). Artificial insemination of sheep and cow with semen treated by $\mathrm{Cu} / \mathrm{Zn}$-superoxide dismutase from fungal Humicola lutea 103, World Journal of Zoology, 1 (1), 36-39.

Szabados, T. (2006). A cervikouterinális inszeminálás eredményességének vizsgálata juhászatokban /Study of effectiveness in cervico-uterinal insemination of ewes/; PhD thesis, University of Western Hungary, Faculty of Agriculture and Food Sciences, Mosonmagyaróvár, Hungary.

Yamaki, K., M. Morisawa, A. Ribadulla, J. Kojima (2003). Sheep semen characteristics and artificial insemination by laparoscopy, Tohoku Journal of Agricultural Research, 54(1-2), 17-26.

http://www.farmanddairy.com/news/ultrasound-and-artificial-insemination-techniques

http://genetic-gains.co.nz

http://genstock.com.au

http://www.innovis.org

http://www.trialanderroracres.com

http://www.topRams.com 


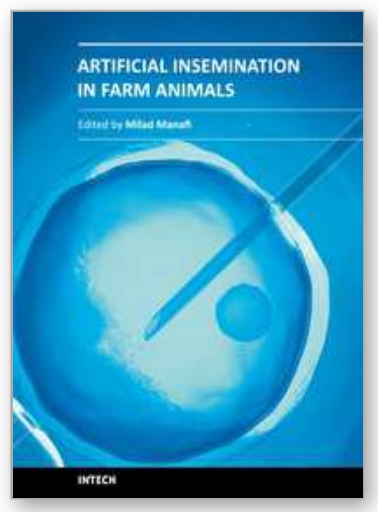

\author{
Artificial Insemination in Farm Animals \\ Edited by Dr. Milad Manafi
}

ISBN 978-953-307-312-5

Hard cover, 300 pages

Publisher InTech

Published online 21, June, 2011

Published in print edition June, 2011

Artificial insemination is used instead of natural mating for reproduction purposes and its chief priority is that the desirable characteristics of a bull or other male livestock animal can be passed on more quickly and to more progeny than if that animal is mated with females in a natural fashion. This book contains under one cover 16 chapters of concise, up-to-date information on artificial insemination in buffalos, ewes, pigs, swine, sheep, goats, pigs and dogs. Cryopreservation effect on sperm quality and fertility, new method and diagnostic test in semen analysis, management factors affecting fertility after cervical insemination, factors of noninfectious nature affecting the fertility, fatty acids effects on reproductive performance of ruminants, particularities of bovine artificial insemination, sperm preparation techniques and reproductive endocrinology diseases are described. This book will explain the advantages and disadvantages of using Al, the various methodologies used in different species, and how Al can be used to improve reproductive efficiency in farm animals.

\title{
How to reference
}

In order to correctly reference this scholarly work, feel free to copy and paste the following:

Sandor Kukovics, Erzsebet Gyoker, Timea Nemeth and Elemer Gergatz (2011). Artificial Insemination of Sheep - Possibilities, Realities and Techniques at the Farm Level, Artificial Insemination in Farm Animals, Dr. Milad Manafi (Ed.), ISBN: 978-953-307-312-5, InTech, Available from:

http://www.intechopen.com/books/artificial-insemination-in-farm-animals/artificial-insemination-of-sheeppossibilities-realities-and-techniques-at-the-farm-level

\section{INTECH}

open science | open minds

\section{InTech Europe}

University Campus STeP Ri

Slavka Krautzeka 83/A

51000 Rijeka, Croatia

Phone: +385 (51) 770447

Fax: +385 (51) 686166

www.intechopen.com

\section{InTech China}

Unit 405, Office Block, Hotel Equatorial Shanghai

No.65, Yan An Road (West), Shanghai, 200040, China 中国上海市延安西路65号上海国际贵都大饭店办公楼 405 单元

Phone: +86-21-62489820

Fax: $+86-21-62489821$ 
(C) 2011 The Author(s). Licensee IntechOpen. This chapter is distributed under the terms of the Creative Commons Attribution-NonCommercialShareAlike-3.0 License, which permits use, distribution and reproduction for non-commercial purposes, provided the original is properly cited and derivative works building on this content are distributed under the same license. 